\title{
Spatial Structure Of Agricultural Biodiversity In Southern Mali
}

\author{
Sidi Dembele \\ Mamy Soumare
}

Department of Geography, Faculty of History and Geography, University of Social Sciences and Management Bamako, Mali

David Gaillard

University of Caen Normandy, France

doi: 10.19044/esj.2016.v12n6p383 URL:http://dx.doi.org/10.19044/esj.2016.v12n6p383

\begin{abstract}
The diversity of cropping systems and varieties plays an important role in the ability of family farms to resist socio-economic and environmental shocks. For better conservation, agricultural diversity needs to be characterized and monitored in space and time. While initially dominated by the elements on price, surfaces, and productions, agricultural monitoring systems have recently incorporated diversity issues. The objective of this work is to analyze the spatial structure of agricultural biodiversity and to explain the links between this structure and the agronomic practices and results in family farms in southern Mali. The methodology was to develop, test, and maintain a conceptual model of spatial data on a sample of three villages. The analysis of these data is based on the spatial distribution of biodiversity and its correlation with the practices and agro-ecological conditions, results, and agronomic performance.

The results show a very large specific and varietal diversity. We do not observe a clear link between spatial distribution and the characteristics of the physical environment, with the exception of the improved variety of Kalafoufigue located on a particular type of slope. The same observation is made when the relationship is between the spatial distribution of the variety and the technical route. Spatial analysis has developed a map of the diversity across the country village. Thus, spatial distribution points plot a surface distribution across local villages, and these results open the way for greater contributions of geographical analysis in agriculture and for scaling territories that remain a challenge for agriculture.
\end{abstract}

Keywords: diversity, variety, spatial structuring, scale 


\section{Résumé}

La diversité des systèmes de culture et des variétés joue un rôle important dans la capacité des agricultures familiales à résister aux chocs socio-économiques et environnementaux. Pour une meilleure conservation, cette diversité agricole a besoin d'être caractérisée et suivie dans l'espace et le temps. Alors qu’ils étaient dominés par des éléments sur le prix, les surfaces et les productions jusqu'à récemment, les systèmes de suivi agricole commencent à intégrer les questions de diversité. L’objectif de ce travail est d'analyser la structuration spatiale de la biodiversité agricole et d'expliquer les liens entre cette structuration et les pratiques et résultats agronomiques dans des exploitations agricoles familiales au Sud du Mali. La méthodologie a consisté à élaborer, tester et alimenter un modèle conceptuel de données spatiales sur un échantillon d'exploitation de trois villages. L'analyse de ces données s’appuie sur la distribution spatiale de la biodiversité et sa corrélation avec les pratiques et les conditions agro-écologiques, les résultats et les performances agronomiques.

Les résultats révèlent une très grande diversité spécifique et variétale. On n’observe pas de lien évident entre distribution spatiale et caractéristiques du milieu physique à l'exception de la variété Kalafoufigue qui semble se localisée sur un type particulier de pente. On fait le même constat quant au lien entre distribution spatiale de la variété et itinéraire technique. L’analyse spatiale a permis d'élaborer une carte de la diversité à l'échelle du territoire village. Ainsi, en passant de répartition spatiale ponctuelle sur des parcelles à une distribution surfacique à l'échelle du terroir villageois, ces résultats ouvrent la voie, d'une part à une plus grande contribution de la géographie dans l'analyse agronomique et d'autre part de passer à l'échelle des territoires qui reste un défis pour l'agronomie.

Mots-Clés: diversité, variété, Structuration spatiale, échelle.

\section{Introduction}

Biodiversity was at the heart of the national and international concerns that led to the Rio Summit in 1992, the Conference on Biodiversity in 2005, the International Year of Biodiversity in 2010, and other programs and institutional innovations. All these actions were meant to raise awareness about the threats to biodiversity and the need for better management and conservation of biological diversity, which can be natural or constructed and maintained by man as in the case of agro-biodiversity. As with global biological diversity, conservation of agro-biodiversity is crucial for food security and the livelihoods of billions of people. About 7,000 plant species have been cultivated and collected to feed humanity since the start of 
agriculture 12,000 years ago (Global Biodiversity, 1992, cited by Sanogo, 2011).

The diversity of cropping systems and varieties plays an important role in the ability of family farms to resist the socio-economic and environmental shocks that until the late 1990s were considered a limiting factor in improving farm productivity systems in the varietal selection process (Gallais, 1990). But in a situation of rainfall uncertainty, farmers reduce the risk by using several varieties and species to survive and produce through all the hazards encountered. The peasant strategy is to grow several varieties with different agronomic traits (earliness, yield, resistance to diseases, pests, drought, etc.) in the same field or in different fields (Baco et al., 2007). This strategy allows farmers to grow varieties according to the best soil conditions in their fields and to satisfy their diverse needs.

For better development, this agricultural biodiversity needs to be characterized and followed in space and time. Until now, agricultural activity monitoring systems have focused on the areas of cultivation, production, and prices. The absence of biodiversity within them is explained not only by the low priority assigned to it in agricultural development projects but also by the complexity of its observation and analysis at different scales.

Indeed, agro-ecological and socio-economic cultures and species are rich and varied in the tropical environment. At the scale of a village territory, landscapes are flat tops of hills and lowlands of different grazing levels. Thus, the fields of a farmer can be dispersed even better than the diversity of the surrounding landscapes. Even on the scale of a single parcel, soil and water conditions change.

Therefore, it is not excluded that the spatial distribution of the interand intra-specific diversity will be performed in a spatial distribution of landscapes and the ecological conditions of the plots or the characteristics of the production systems. The study is conducted within this framework to analyze the spatial structure agro-biodiversity in the cotton zone of Mali.

\section{Overview of the Study Sites}

The research was conducted in the cotton zone south of Mali and in three villages (Dampérakuy, Siou, and Diou) spread over a north-south climatic gradient with 700, 900, and $1100 \mathrm{~mm}$ of annual rainfall, respectively.

Like other Sahelian countries, Mali's agriculture is largely dependent upon climatic conditions, particularly rainfall. The spatial distribution of rainfall, combined with ecological conditions, helped partition the country into agricultural production zones. In total, the country is divided into six southern production areas to the north. The southern area is divided based on 
key elements such as climate, vegetation, population densities, cultural habits, and agricultural policies.

The three villages are located as follows: Damperakuy (Tominian) in the north, Siou (Koutiala) in the center, and Diou (Kadiolo) in the south.

Village of Damperakuy: This village is located in the extreme northeast of the cotton zone, covering an area of 1371 hectares. The area is characterized by a very low or moderate majority of farms equipped with one or two draft oxen and with little room for breeding. Cropping systems are based on a main rotation of millet/sorghum and, incidentally, peanuts. The landscape is very flat with a series of small mounds, whose tops are not cultivated. A degraded residual vegetation covers these mounds, and this area is known as the saltus. The ager, which is the part of the agricultural land for crops, consists of a series of fallow and cultivated fields of very short duration (two to three years). And men, with the number of operations.

Village of Siou: This village contains an area of 4175 hectares with about $900 \mathrm{~mm}$ of rain per year and population densities of $30-40 / \mathrm{km}^{2}$. It corresponds to the southern part of the Old Cotton Basin. The same types of operations as the Old North Basin characterizes this area, with cotton/corn the most common crop and a large minority of the large cotton farms (about $1 / 10$ of farms) featuring a significant level of equipment (two teams) and a cattle herd of about 20 heads. The saltus is of a relatively large size, and the extension of the ager continues. The new clearing and newly settled farming hamlets are visible in the landscape. The ager/saltus system is in equilibrium, and the ager is still expandable.

Village of Diou: This village is located in the extreme southeast of the marginal parts of the cotton areas, where two-thirds of the farms are equipped. The larger farms are equipped with a large herd of cattle. Cropping systems are based on corn/sorghum or corn/cotton. Apart from the immediate vicinity of the villages, fields are scattered in space and are rarely contiguous. 


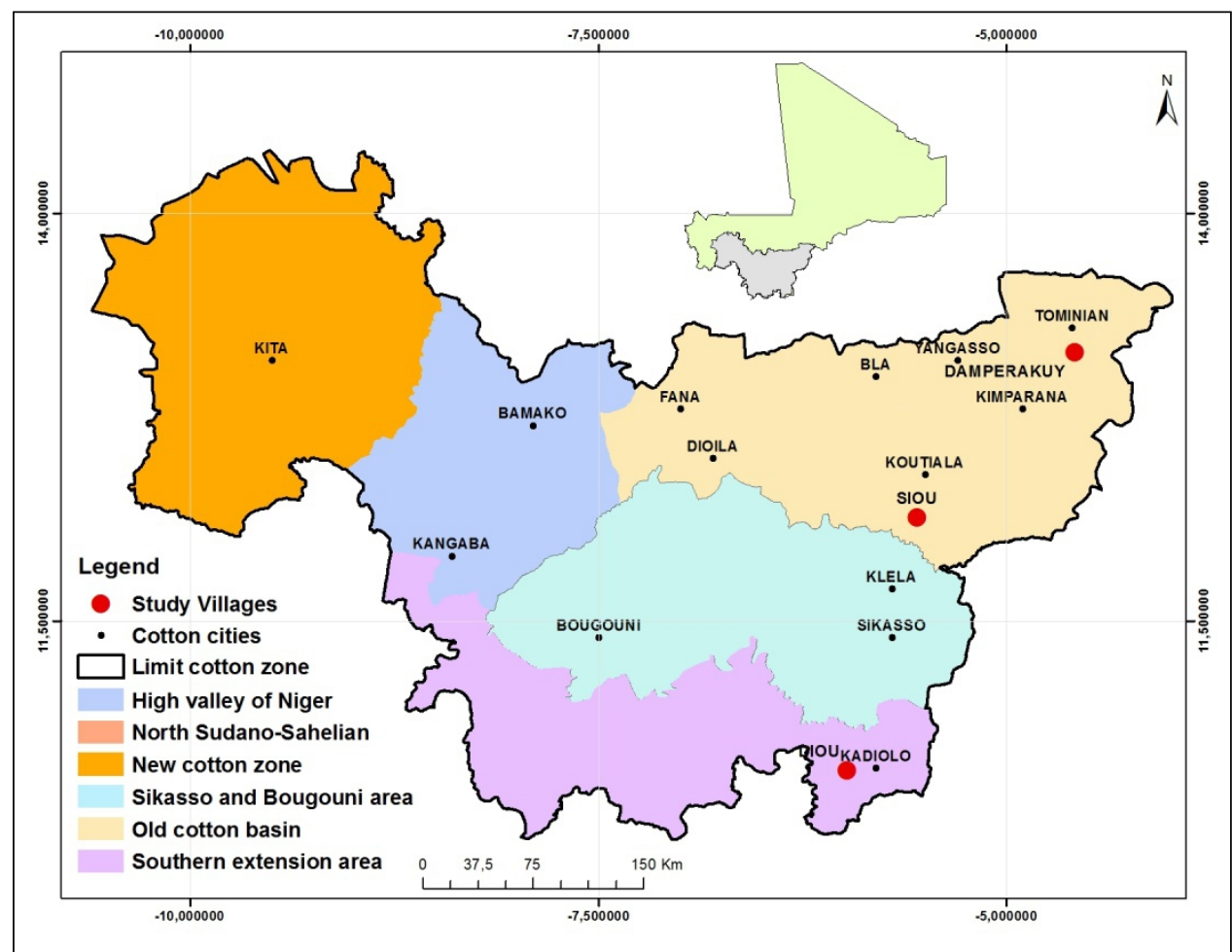

Figure 1: Location of study sites in the cotton zone of Mali

\section{Methodology}

The approach applied in the context of this research clearly focuses on geographic information science and shows how geographic information can provide agricultural science alternative ways to use the data it produces. This approach is based on a sampling system at several levels and on a spatial data processing system that includes innovative agronomy with a series of cross-analyses. The methodology will explore the spatial distribution of biodiversity and its correlation with the practices and agroecological conditions, results, and agronomic performance.

\subsection{Sampling system and prospecting}

The cotton growing area in Mali was cut on June 6, and it can be divided into three farming systems: the cultivation system and fallow without cotton, the continuous and intensive cultivation system, and the cultivation system and fallow with cotton. The study takes place in three villages chosen for this typology of agrarian systems and for the lack of research program to select the specific development or dissemination of new varieties, as the prolonged presence of research projects can probably influence biodiversity.

In each village, we first made a structural survey of all farms, followed by a random draw with a sampling rate of at least $50 \%+1$ 
individual. Thus, we obtained a sample of 23 farms in Damperakuy (Tominian), 25 in Siou (Koutiala), and 23 in Diou (Kadiolo) to characterize their functioning practices in integrating socio-economic and spatial dimensions. The sampling rate, which uses at least half the farms, has the advantage of extrapolating the results with acceptable margins of error for considering all possibilities.

Within this sample, an inventory was made of the plots during the 2011 growing season. After this inventory, all millet and sorghum plots were selected to be surveyed. In this survey, we took care to note the geographical coordinates of the centroid of each plot, which will be linked to other information about the plot (range, area, production, etc.)

\subsection{Processing spatial data in agronomy}

The collected data is processed on two levels. The first is a basic salary through the calculation of averages and graphical representation. The second, which deals exclusively with spatial data, was made with three distinct methods. The first method was to identify the spatial distribution of species and varieties through longitude and latitude $(\mathrm{x}, \mathrm{y})$ plots. This method can handle large amounts of attribute information to reveal the underlying spatial structures (Joost, 2008).

The second method is a function of spatial autocorrelation (Moran I) and determines whether there is logic in the spatial distribution of species or varieties. It measures the spatial correlation according to the location of the entities (plots) with respect to a quantitative attribute data, such as the area or the production. The application of the function and whether the phenomenon can be observed is aggregated (if the Z-score is greater than 2), scattered (when Z-score is less than 1), or random (if Z-score is between -1 and 2).

The third method aimed to move discontinuous point representations of plots to a surface representation to produce diversity scale maps of the village, which is a spatial aggregate function agronomic data based on the concept of spatial density and the actual position of species and varieties. This method performs data aggregation by calculating the density using the kernel method on a grid. The kernel density method (kernel density) assumes that the density of a square is inseparable from that of its neighbors. In short, it assumes that two individuals that are geographically close will tend to look alike.

\section{Results and Discussion}

The following results are threefold. First, the results will provide the general traits of agro-biodiversity (specific and varietal diversity) in the three villages, the importance of the different cultures, and the main results of production operations. Next, they will present the spatial structure of agro- 
biodiversity, addressing both the localization of plots in different units and the relations between this location and the existence of less environmentally favorable conditions such as the altitude, the gradient, and the self-spatial correlation of sorghum, millet, and certain other varieties of plots. Finally, the results are presented by interpolating the data to produce maps or specific varietal diversity across the land.

\subsection{Characterization of the farms and their farming systems}

3.1.1. Plant species diversity. In Damperakuy (Figure 2), which is located in the north where rainfall rarely exceeds $700 \mathrm{~mm}$ per season, millet and sorghum constitute the bulk of the crops; they are used in biennial or triennial rotation with peanuts. These two crops account for more than $70 \%$ of crop species in the village or area. Peanut, the main cash crop in the soil, is cultivated by $17.44 \%$ of respondents. Although the land is in the cotton zone, the rainfall and soil conditions did not permit the cultivating of cotton. Other no less important crops are fonio and sesame.

In the second village, Siou (Figure 3), maize, sorghum, and cotton are the main crops. Sorghum is widely grown, present in $37.77 \%$ of farms, followed by cotton (31.26\%). Despite its demands for water and fertilizer, maize $(19.77 \%)$ joined sorghum to constitute the backbone of the cereal crops. Millet is present on about $9 \%$ of farms, while peanuts $(1.91 \%)$, cowpeas $(0.20 \%)$, and rice $(0.21 \%)$ are less cultivated.

In Diou (Figure 4), corn is the dominant species with $42.80 \%$. This can be explained in particular by the rainfall, which is generally above 1000 $\mathrm{mm}$ of water per year, the presence of fertile lands, and the back benefits of cotton, which is very often grown in rotation with corn. Cotton, the main cash crop, is second at just under $25 \%$. With the presence of lowlands and rain, rice is also an important crop (16.64\%). We also note other crops such as sorghum (6.55\%), peanuts (5.61\%), millet (1.49\%), vandzou (1.12\%), and cowpeas (less than 1\%). In short, Diou features more specific diversity. 


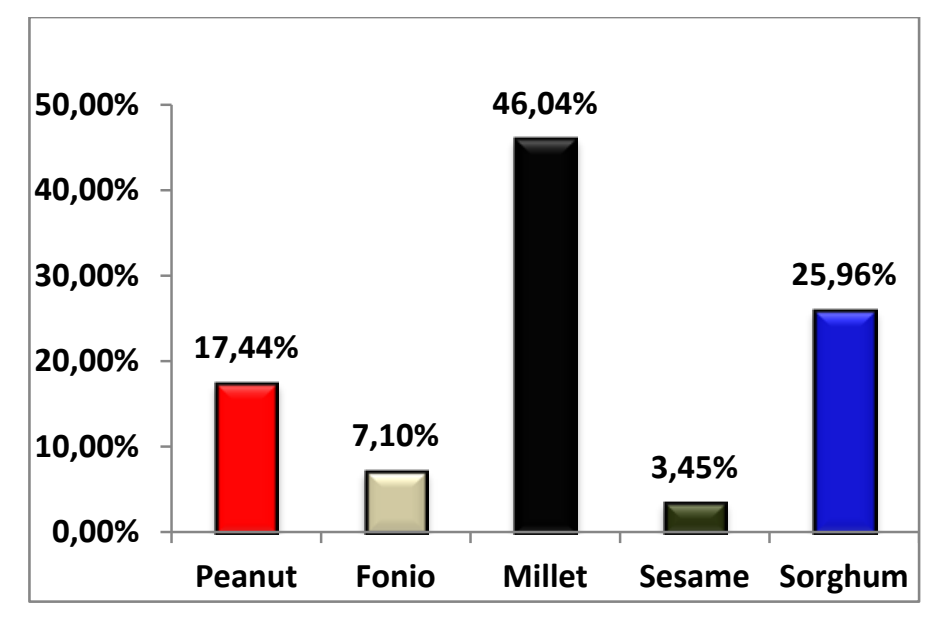

Figure 2: The crop species in the soil of Dampérakuy

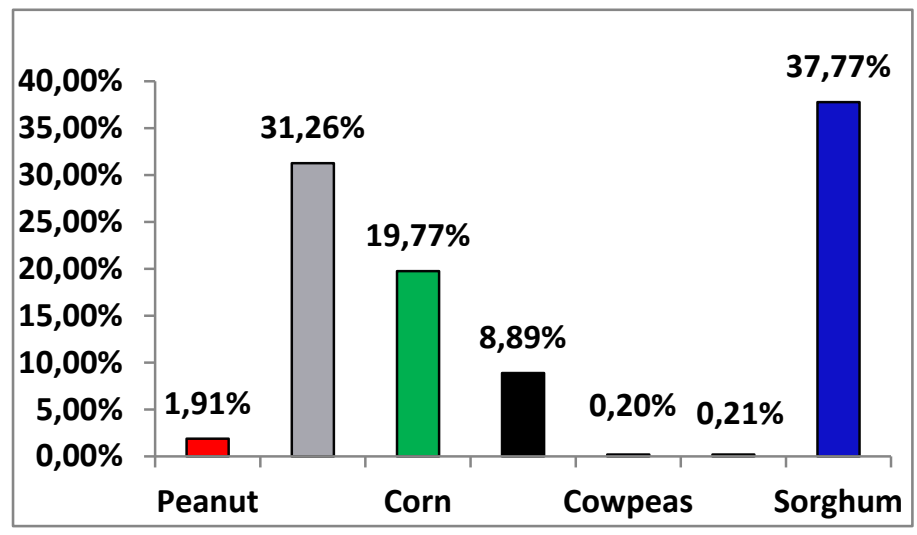

Figure 3: The crop species in the land of Siou

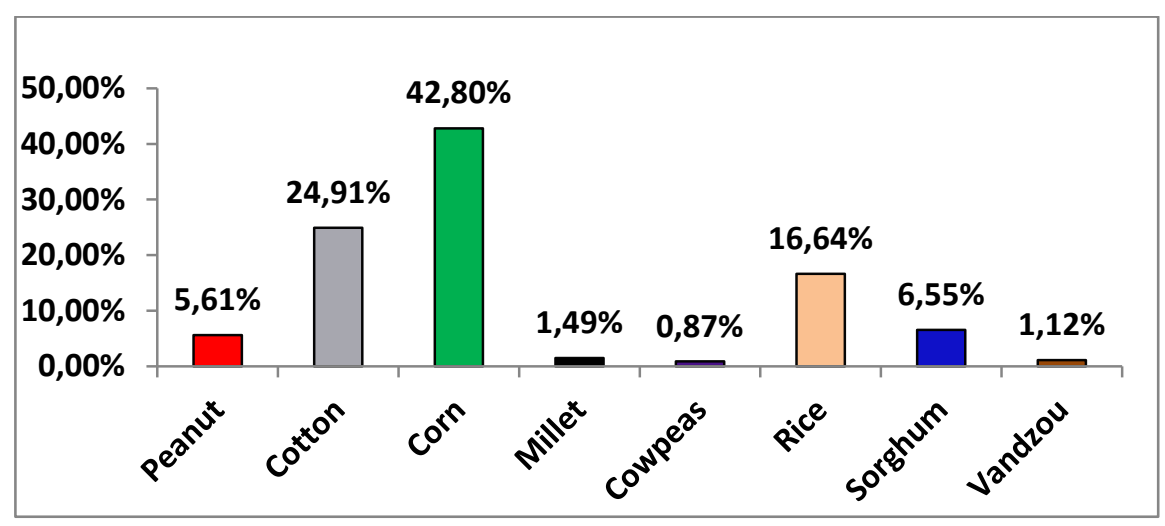

Figure 4: The crop species in the soil of Diou 
3.1.2. Spatial structure of the varietal diversity of millet and sorghum. The variety names are in the national language of Bambara (the majority language in Mali), Bomou for Dampérakuy, Minianka for Siou, and Senoufo for Diou. Some varieties can have the same names but different characteristics from one village to another. Further varieties can have different names but very similar characteristics, even identical. Of the 37 plots of millet surveyed in Dampérakuy, over $65 \%$ were occupied by the local variety Bouefoue. It is either monocultured (38.73\%) or grown in association with another local variety, Dassoura (25\%). The cartographic analysis of the spatial distribution of these two varieties showed a remarkable spatial dispersion in all soils and the entire toposequence (Figure 5). The other varieties of millet are Denou (12.61\%), which is localized exclusively to the north; Toronio (6.30\%), which is found in the northwest; and Doufoignana, which is a variety with a single parcel located in the southwest.

In Siou, the Chotigue variety was present in eight of the 14 plots (60\%; Figure 6). It is indicated everywhere on land suitable for farming or in areas where the altitude is less than $300 \mathrm{~m}$. In this village, $60 \%$ of the soil is not conducive to farming; this is the part of the soil where the altitude is above 300m. The combination of the Chotigue and Pounkanangan varieties, a Sanko monoculture, and a pure culture of Pounkanangan each represent $11.11 \%$ of the millet varieties in Siou prospecting plots.

The village of Diou (Figure 7) is traditionally an area of maize and sorghum. The millet crop is virtually nonexistent, and the only two plots of millet are located in the east. 


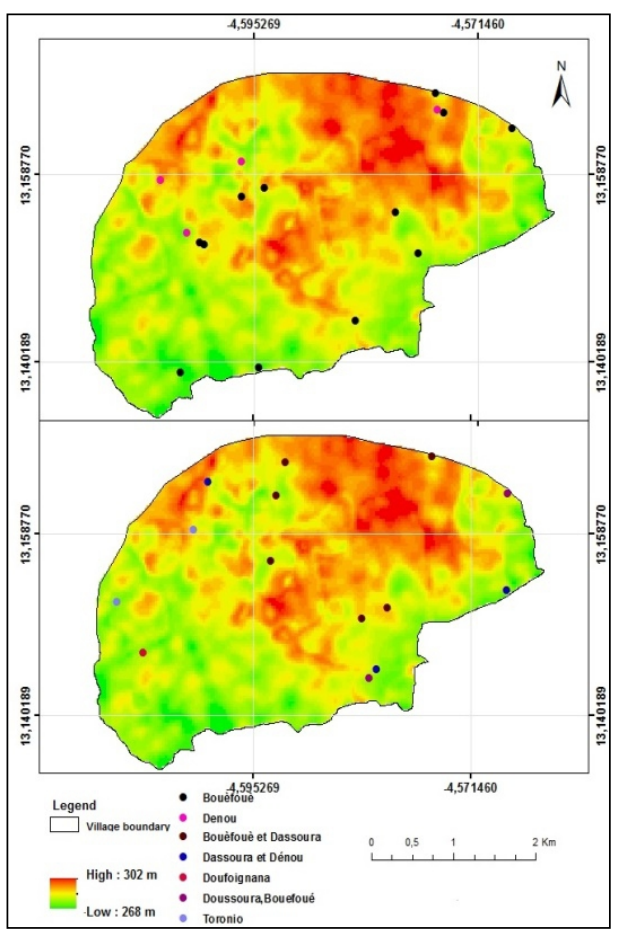

Figure 5: spatialization of millet varieties in Dampérakuy

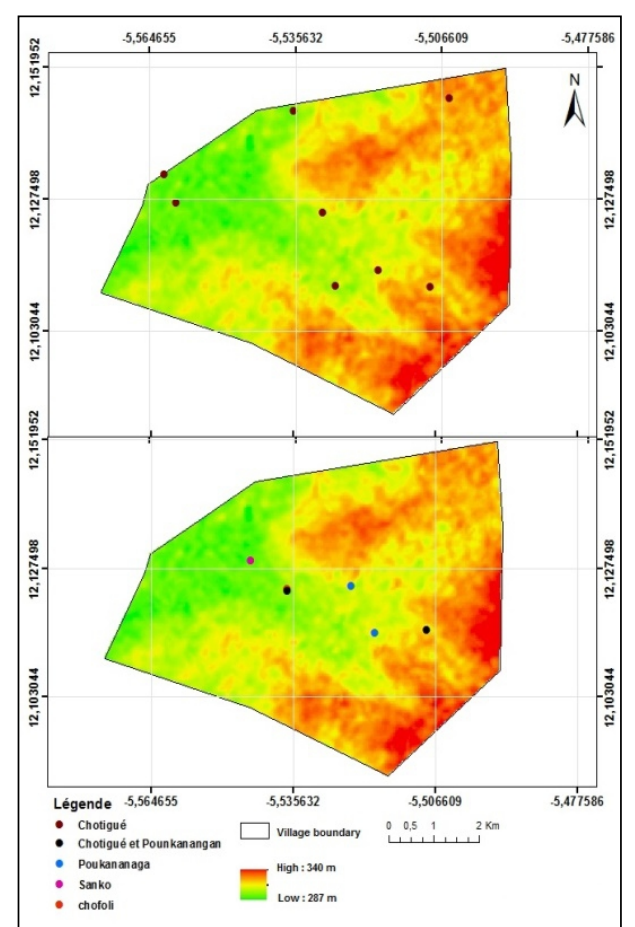

Figure 6: spatialization of millet varieties in Siou

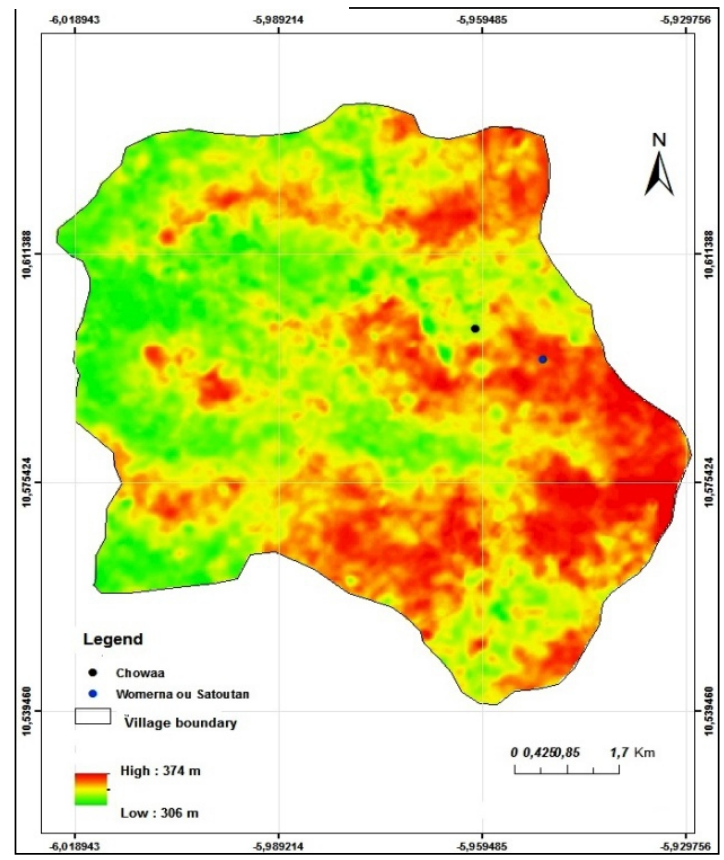

Figure 7: spatialization of millet varieties in Diou 
Unlike millet, which has some largely predominate varieties, the distribution of sorghum varieties is more balanced in the village of Dampérakuy (Figure 8). They can be classified into three categories. The first is the most dominant, ranging from 11 to $13.22 \%$, and includes the varieties of Jacumbe and Doubirou; Ario and Baba Tassi; Jacumbe; and Doubirou, Lozomounou, and Samafounou. The second is from 6 to 9.92\% and includes Seguetana, Ario, Hariho, Seguetana, Lozomonou, and Doubirou; Seguetana and Jacumbe. The third class ranges from 1.65 to 4\% and is composed of Ario and Baba Tassi; Doubirou, Lozomounou, Samafounou, and Seguetana; Lozomounou, Seguetana, Jacumbe, and Samafounou; Bouefoue, Doubirou, and Lozomounou; Doubirou and Lozomounou; Doubirou, Baba Tassi, and Jacumbe.

In the sorghum plots of Siou, Kalafoufigue (white and early) is the most common at $30.36 \%$, and Seguetana Diema (a variety that resists Striga) is the other dominant variety at $28.84 \%$. The first variety is located from west to east on the strip of arable land, while the second variety is much more concentrated in the center with some parcels to the east. The other varieties are only slightly grown; Kalafoufigue and Gnefarawoule are at less than 10\%, followed by Kalagnigue (7.59\%), Flakeba (6.83\%), and Gnefarawoule (5.31\%). The association between Kalafoufigue and Seguetanadie is $4.17 \%$. The varieties of Gnefarawoule-Seguetanadie and Seguetana-Gnesoroko-Gnefarawoule each represent nearly 3\%. The Kalafoufigue and Kalafougniga varieties each have 1.52\%.

Finally, in the village of Diou (Figure 9), the Seguetanadie is the most dominant variety with about half of the sorghum surfaces. This variety remains dispersed throughout the village, with the other varieties being Kolawale and Kende.

In conclusion, we note that the more one moves to the south of the cotton area, the more mixed cultures decrease, which can be explained by the increased rainfall in these areas. The villages of Siou and Diou face a problem of Striga, which explains the abundance of the Seguetana variety. The varieties and species are scattered randomly across the terroirs. With such differences in the spatial distribution, we see that there is logic in locating plots of sorghum or millet in the three villages. Other methods of analysis will be used to further explore the possibilities of spatial logic in the distribution of varieties and species. 


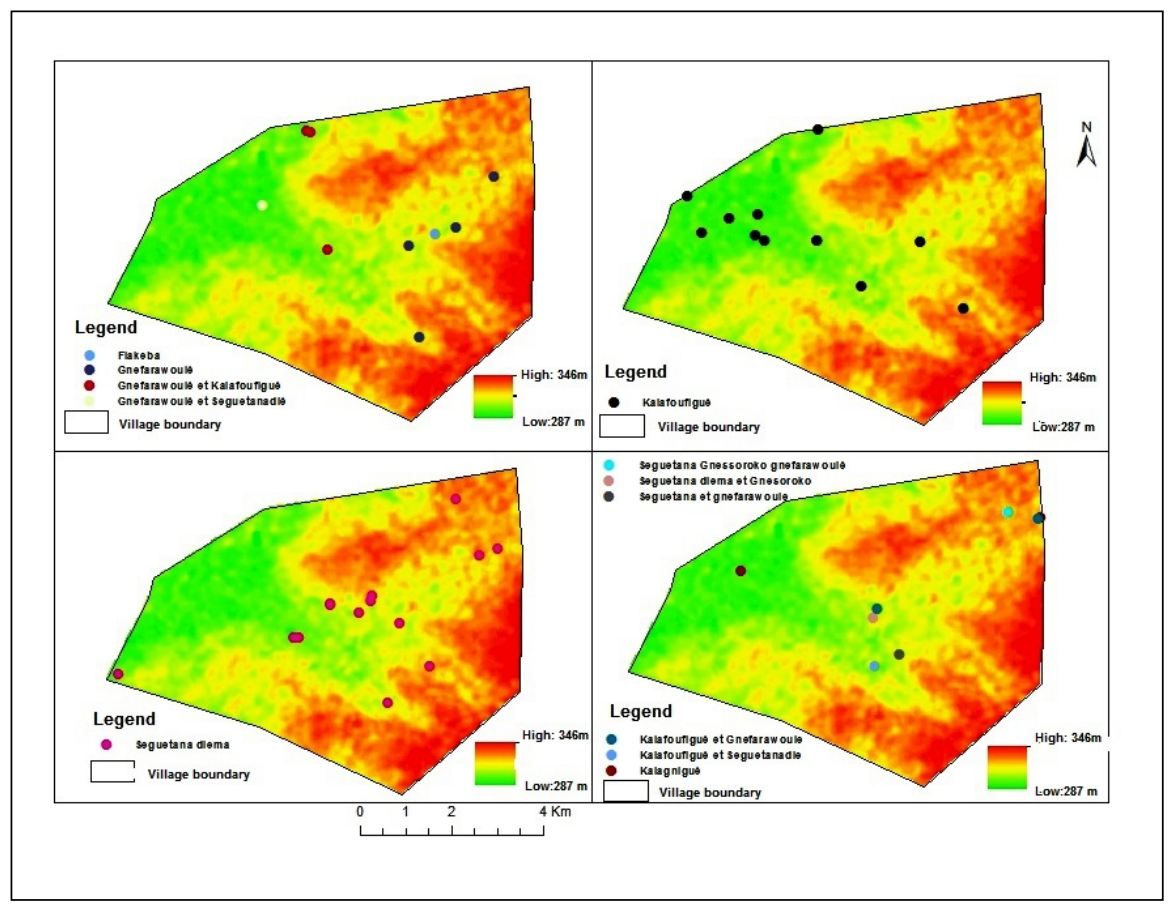

Figure 8: spatial sorghum varieties in Siou

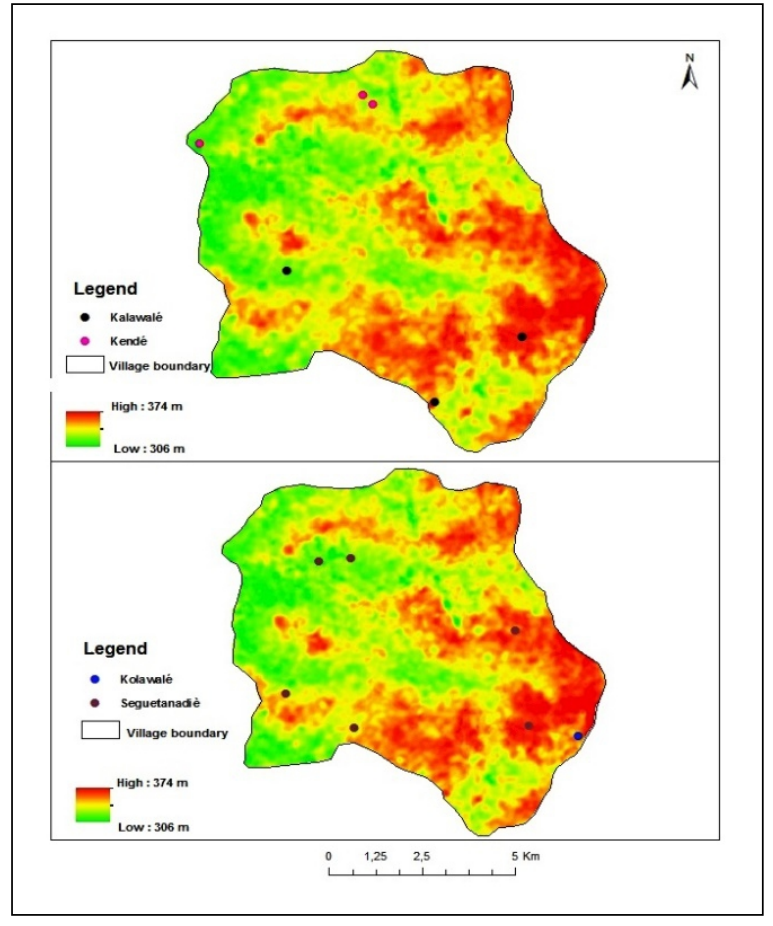

Figure 9: spatial sorghum varieties in Diou 
3.1.3. Cropping systems at the farm level. There is a variability in crop systems (Table 1 ) in the three agro-ecological zones. The villages of Siou and Diou have almost similar cultural systems. In both localities, cotton is rotated first, followed by maize. Corn is a demanding crop for fertilizers and receives rear effects from cotton. The two main crops receive good mineral fertilizers and occupy a prominent place in the farms. Cotton is the culture that first receives organic manure in these two villages (culture system: SC1, SC3). The type (SC2) SC1 triennial usually precedes the Triennial rotation is preferably practiced on plots less abundantly smoke and reported slightly lower earnings at the unit area (Dufumier 2005). The SC4 and SC5, respectively, are based on rain-fed rice and legumes as secondary crops, and their presence contributes to the diversification of production. In Damperakuy, the SC6 and SC7 are the dominant farming systems based on cereals (millet and sorghum). These grains are not fertilized with mineral fertilizer but with a small amount of organic manure. The SC9 receives no fertilizer and precedes the SC8. The areas occupied by the SC8 and SC9 are not as important as those reserved for SC6 and SC7. In the villages of Siou and Diou, cotton is rotated first, followed by maize. This culture system is the most dominant in both zones. In Dampérakuy, millet is rotated first, followed by sorghum, and these plots are fertilized with mineral fertilizer.

Table 1: Cropping systems (SC) on the scale of the operation

\begin{tabular}{|c|c|c|c|c|}
\hline Village & SC & Cultured & $\begin{array}{l}\text { Species Cycle } \\
\text { Rotation }\end{array}$ & Technical Route \\
\hline \multirow{5}{*}{$\begin{array}{l}\text { Siou } \\
\text { Diou }\end{array}$} & $\begin{array}{l}\text { SC1 } \\
\end{array}$ & $\begin{array}{l}\text { Cotton - corn - } \\
\text { millet - sorghum }\end{array}$ & Quadrennial & $\begin{array}{l}\text { Fo + cco + urea + herbicide + } \\
\text { insecticide on cotton; cce }+ \text { urea on } \\
\text { maize }\end{array}$ \\
\hline & SC2 & $\begin{array}{l}\text { Corn - sorghum - } \\
\text { millet }\end{array}$ & Triennial & Cce + urea on maize \\
\hline & SC3 & Cotton - corn & Biennial & $\begin{array}{l}\text { Fo + cco + urea + herbicide }+ \\
\text { insecticide on cotton; cce }+ \text { urea on } \\
\text { maize }\end{array}$ \\
\hline & SC4 & Upland rice & Monoculture & Without fertilizer \\
\hline & SC5 & $\begin{array}{l}\text { Peanut - } \\
\text { voandzou }\end{array}$ & Biennial & Without fertilizer \\
\hline \multirow{4}{*}{ Damperakuy } & SC6 & $\begin{array}{l}\text { Millet - fonio and } \\
\text { sorghum - fallow }\end{array}$ & Sort and or more & $\begin{array}{l}\text { Providing a small amount of Fo, } \\
\text { either millet or sorghum }\end{array}$ \\
\hline & SC7 & $\begin{array}{l}\text { Millet and } \\
\text { sorghum and } \\
\text { peanut or fonio }\end{array}$ & $\begin{array}{l}\text { Sorting or } \\
\text { quadrennial }\end{array}$ & $\begin{array}{l}\text { Providing a small amount of Fo, on } \\
\text { millet }\end{array}$ \\
\hline & SC8 & Millet - peanut & Biennial & Without fertilizer \\
\hline & SC9 & Peanut - fonio & Biennial & Without fertilizer \\
\hline
\end{tabular}

Fo = organic manure; cco = cotton complex; cce = complex cereal

Source: (Dembele, 2012) 


\subsection{Correlation between spatial distribution and ecological conditions}

The spatial autocorrelation tests are made for the village of Siou with five basic geographic layers: 1) all millet and sorghum plots, 2) millet plots, 3) sorghum plots, 4) the three most dominant varieties of sorghum (Kalafoufigue, Gnefarawoule, and Seguetana), and 5) the most dominant variety of millet (Chotigue). These layers are crossed in each case with two variables: altitude and slope. The choice of Siou is explained by the large number of millet plots, as at least 30 units are required to make a relevant test.

Altitude. Of the five basic layers (millet/sorghum, millet, sorghum, and the varieties Kalafoufigue, Gnefarawoule, and Chotigue), spatial distribution is random. Millet plots and the sorghum variety Seguetana seem grouped according to the test (value). This is explained by the fact that, in this area, all the arable land is located in the same altitudes, as the rest of the area at high altitudes is not suitable for farming.

Slope. Apart from the Kalafoufigue sorghum variety, which is highly spatially correlated with lower slopes of 0 to 1.03 degrees, the spatial distribution of the other species and varieties is random.

Latitude. The spatial distribution of rainfall in the cotton zone of Mali is latitudinal; therefore, it was interesting to test whether the spatial species and varieties are related to rainfall. At this stage, we can note the presence of a third spatial distribution mode of millet/sorghum plots and sorghum plots, as these species have a tendency for dispersion. The plots of millet, the sorghum variety Gnefarawoule and the millet variety Chotigue seem to be grouped according to latitude. The sorghum varieties Kalafoufigue and Seguetana have a random distribution.

Longitude. According to this test, the millet/sorghum plots and all sorghum plots are dispersed by latitude. However, the plots of millet, the sorghum variety Seguetana, and the millet variety Chotigue have a tendency to aggregate. The remaining sorghum varieties, Kalafoufigue and Gnefarawoule, are randomly distributed.

\begin{tabular}{|l|l|l|l|l|}
\hline Variables & $\begin{array}{l}\text { Altitude } \\
\text { Z-Score }\end{array}$ & $\begin{array}{l}\text { On the } \\
\text { Slope } \\
\text { Z-Score }\end{array}$ & $\begin{array}{l}\text { Longitude X } \\
\text { Z-Score }\end{array}$ & $\begin{array}{l}\text { Latitude Y } \\
\text { Z-Score }\end{array}$ \\
\hline Sorghum plot & 0.27 & 0.26 & -3.09 & -4.07 \\
\hline Millet plot & 3.27 & 0.90 & 3.23 & 3.67 \\
\hline Millet/Sorghum plot & 0.30 & 0.30 & -1.88 & -3.07 \\
\hline Sorghum variety Kalafoufigue plot & 0.40 & 2.02 & 0.21 & 0.37 \\
\hline $\begin{array}{l}\text { Sorghum variety } \\
\text { Gnéfarawoulé plot }\end{array}$ & 1.02 & 1.02 & 1.13 & 2.12 \\
\hline $\begin{array}{l}\text { Sorghum variety } \\
\text { Seguetana plot }\end{array}$ & 3.34 & 1.46 & 2.19 & 0.59 \\
\hline \begin{tabular}{l} 
Millet variety Chotigue plot \\
\hline
\end{tabular} & 1.12 & -0.90 & 3.08 & 2.71 \\
\hline
\end{tabular}


Z-score is greater than 2: the phenomenon observed is associated.

Z-score is less than 1: the phenomenon observed is dispersed.

Z-score is between -1 and 2: the phenomenon observed is random.

By relating the spatial distribution of species and varieties to their performance in a thematic map, the findings offer a new perspective to agronomy in the management and processing of data.

In Siou (Figure 11), Kalafoufigue sorghum varieties and yields of Seguetana Diema exceed those of other varieties, with more than 1 ton $500 \mathrm{~kg} / \mathrm{ha}$. The yields of these varieties are not stable, with a significant change noted from one soil to another. They can often be as low as 500 $\mathrm{kg} / \mathrm{ha}$. We are seeing a greater dispersion of the yields on all soil types. The millet variety Chotigue represents nearly 63\% (Figure 12) and was spotted everywhere on soils suitable for agriculture. In terms of yield, it varies between 1 ton $500 \mathrm{~kg}$ to $355 \mathrm{~kg} / \mathrm{ha}$. Poukananaga also showed outstanding performance, with over 1 ton $500 \mathrm{~kg}$.

In the village of Dampérakuy, the sorghum Seguetana variety monoculture is the most productive, with a yield between 801 to $1200 \mathrm{~kg} / \mathrm{ha}$ (Figure 13), and it is localized on ferruginous leached soils. Three millet varieties, Bouefoue, Toronio, and Doufoignana, have outstanding performance (Figure 14), and their yields exceed 1.5 ton/ha, but the performance of the local variety Bouefoue is not stable throughout the village.

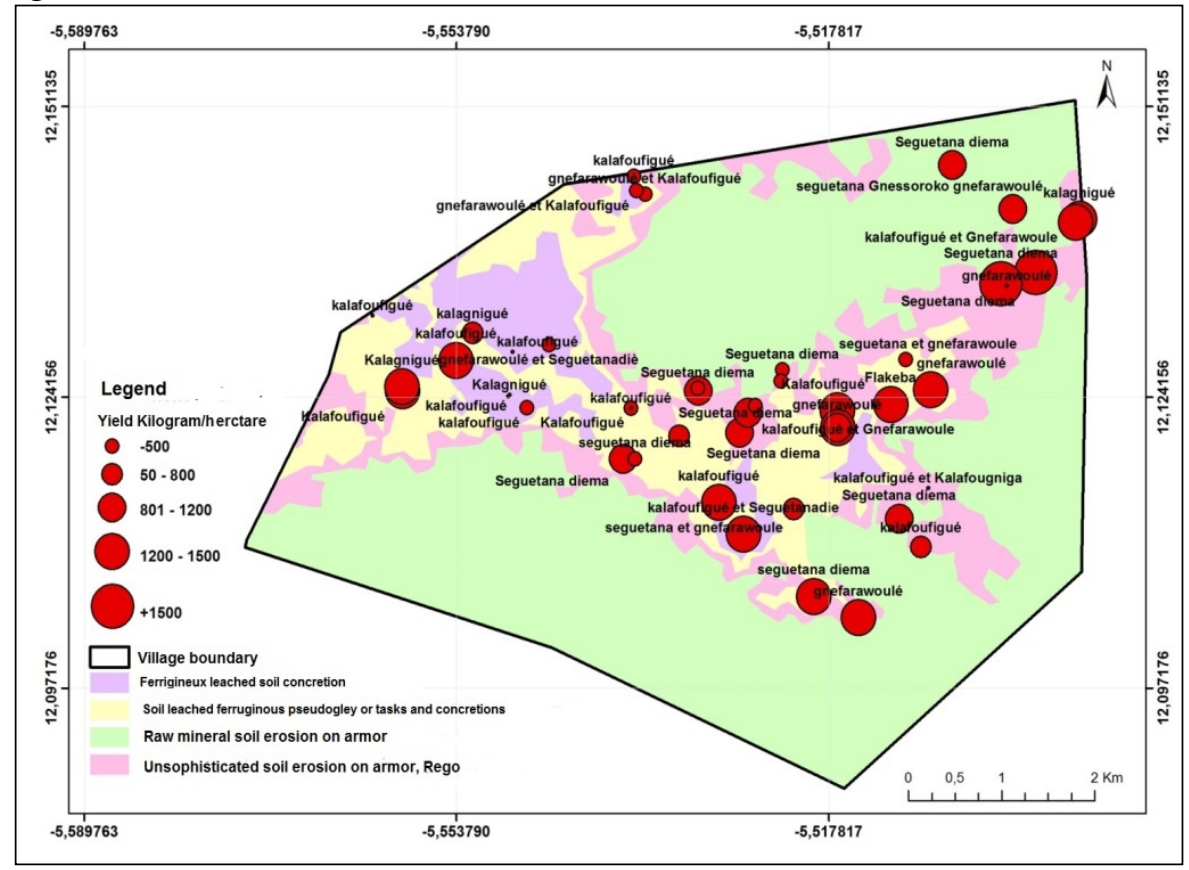

Figure 10: Spatial distribution of sorghum yields in Siou 


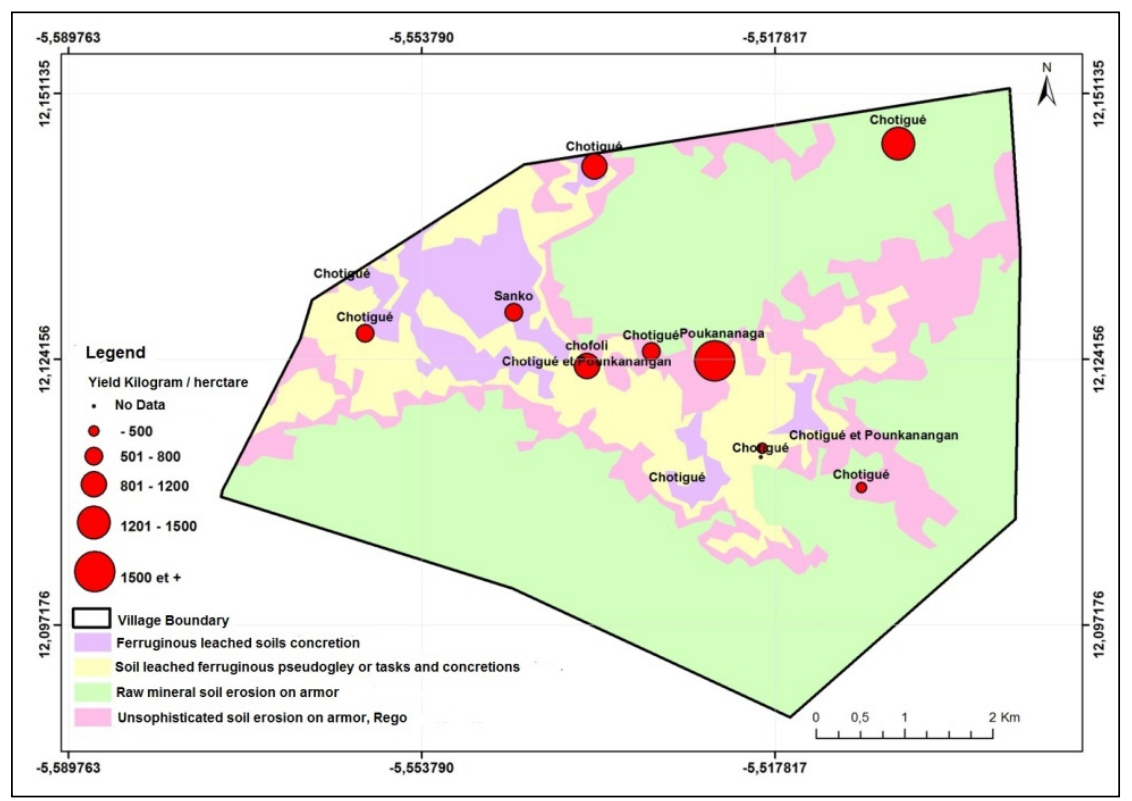

Figure 11: Spatial distribution of millet yields in Siou

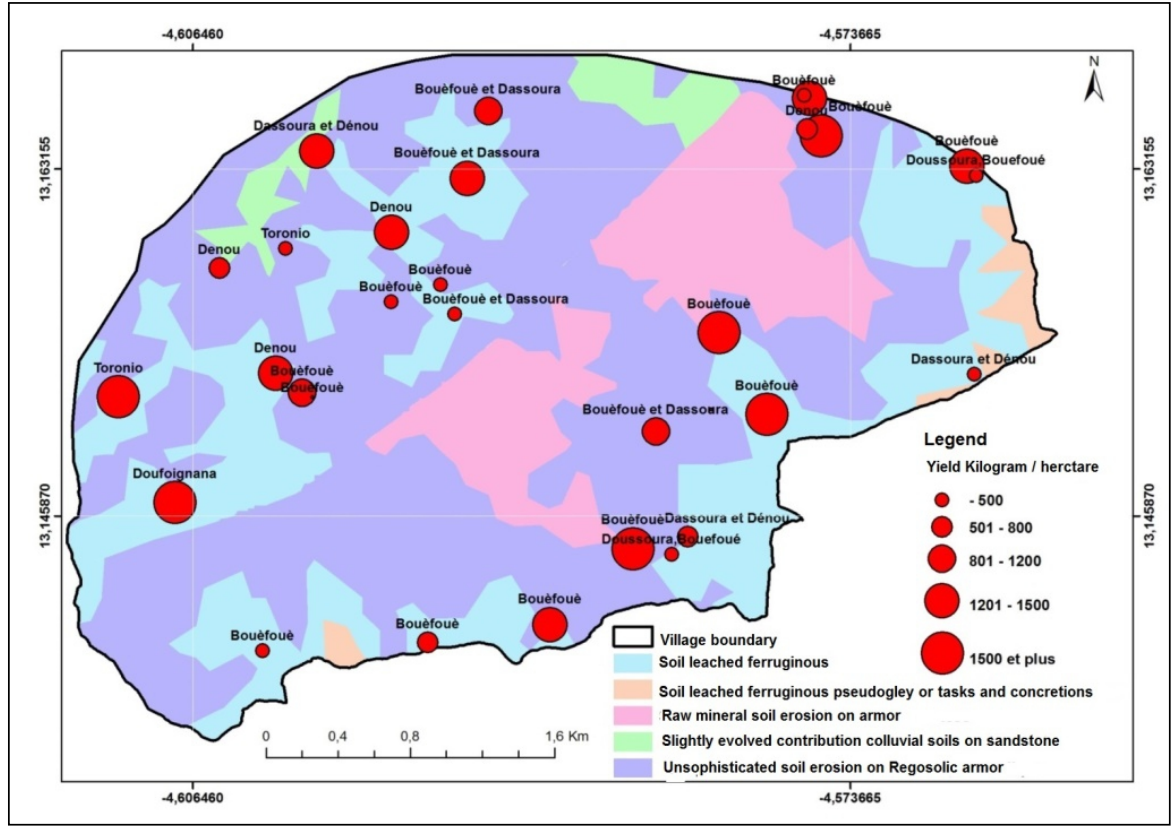

Figure 12: Spatial distribution of millet yields in Dampérakuy

\subsection{The soles of specific and varietal diversity}

The creation of varieties of cards and soles of species is based on the scale changes at the heart of spatial analysis and data aggregation. The method used here is that of kernel density. 
In Siou, the results show that the density kernels for millet density are much higher in the east-west band than in the rest of the soil. In Damperakuy, density is much stronger than viewed in the west-northwest. There is also a high density in the southeast and the northeast. Regarding the third village, Diou, we only have a few millet and sorghum plots (15), which together are spread over the land; the result of spatial aggregation can only be in place because the value 'no data' is assigned to all parties who do not own land on a given search radius.

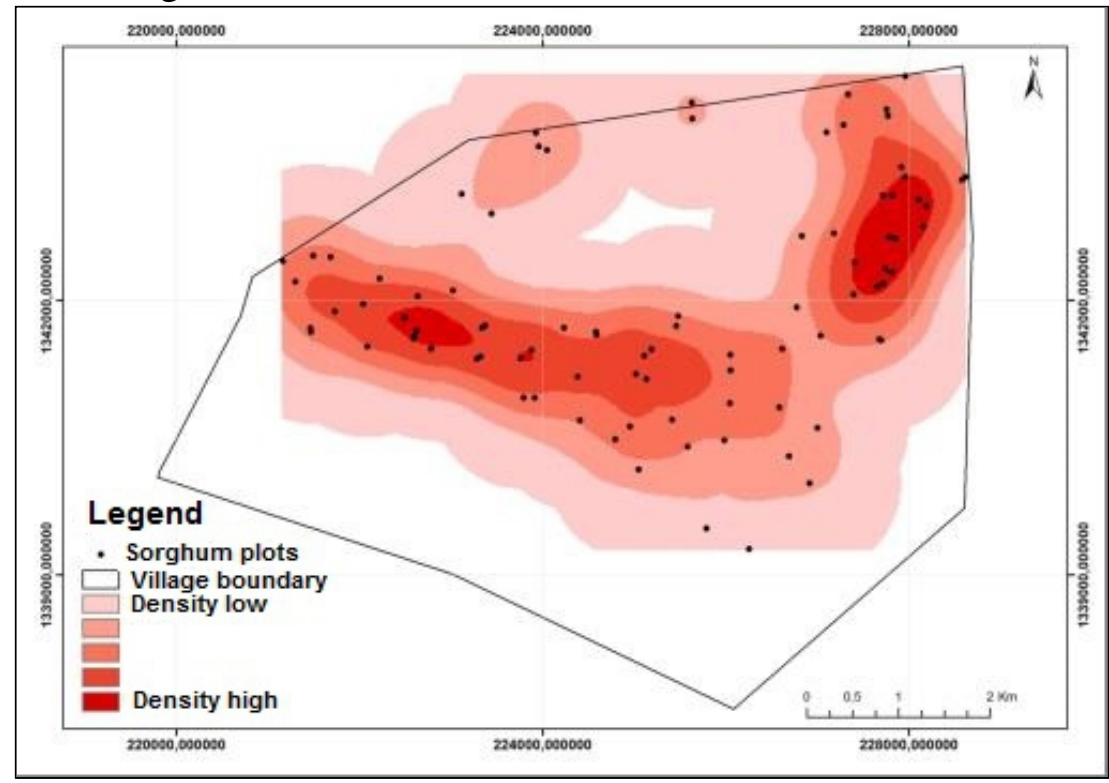

Figure 13: Map of the sorghum density Siou

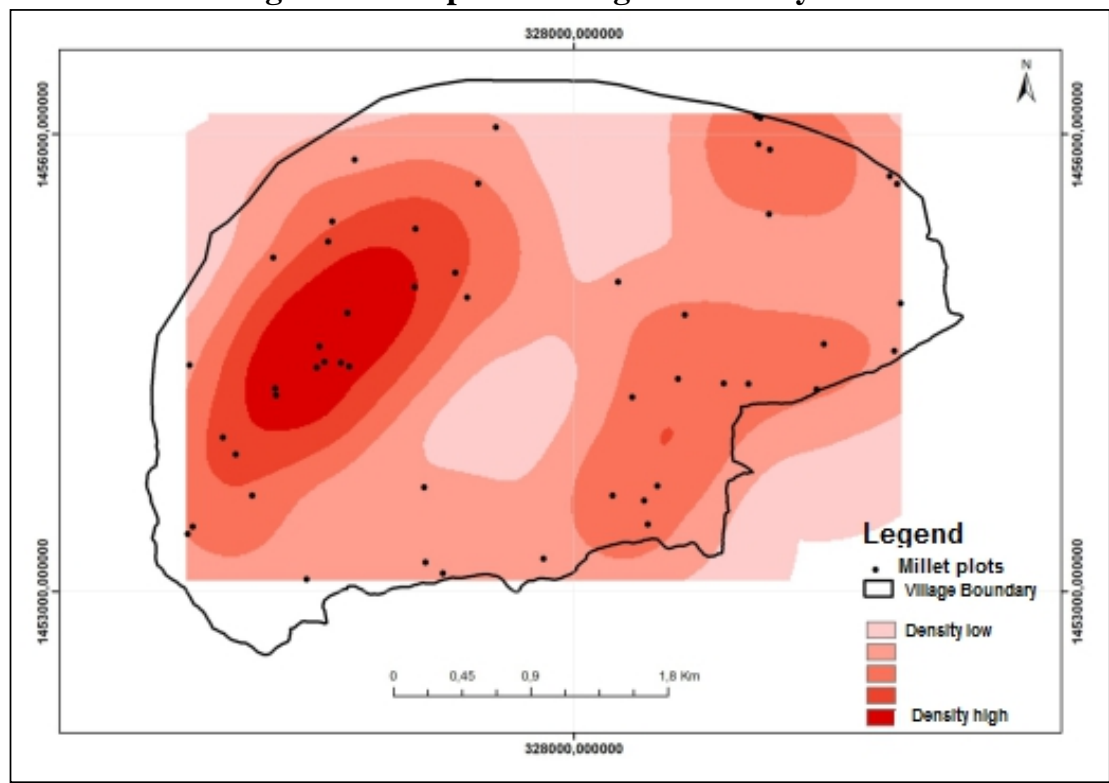

Figure 14: Map of the millet density in Dampérakuy 


\section{Conclusion}

The spatial distribution profiles of the varietal diversity of the villages offer a new agronomist tool for assessing the risk of biodiversity loss. Thus, through an ad hoc spatial distribution of the surface distribution across the village lands, these results open the way, first, to a greater contribution of geography in agronomic analysis and, second, to scale territories that remain a challenge for agronomy.

Species distribution and varieties maps highlight the different spatial distribution patterns. The spatial distribution model most prevalent in the three territories is that of a random distribution. Indeed, in most cases tnere is a large spatial distribution of millet and sorghum varieties across the whole territory, and that distribution does not take into account specific ecological conditions. The spatial autocorrelation tests confirm these results. This work was primarily driven by its methods, and the methods developed during this research open up new prospects for the treatment of agronomic data. These methods are the changes of scale, the different spatial autocorrelation tests, and the spatial analysis of the spatial distribution of species and varieties through their geographical positions.

\section{References:}

BACO M. N., 2007 « Gestion locale de la diversité cultivée au nord bénin: éléments pour une politique publique de conservation de l'agrobiodiversité de l'igname (dioscorea Spp) » thèse de l'université d’Orléans, 406 pages.

Baco M N et al., 2007 «Les savoirs paysans traditionnels conservent-ils encore 1'agrobiodiversité au Bénin ? » Article scientifique, pages 10

BAIZE D, RODDIER S., 1992 «Les typologies pédologiques fines comme outils d'extrapolation spatiale. Application à une cartographie pédogéochimique en Avallonnais (France) » Article scientifique. Page 7

BAZILE D et al., 2006 «Les paysans au cœur de la construction de règles collectives de gestion de l'agrobiodiversité. » Article scientifique pages 24

BAZILE D, DEMBELE S, SOUMARE M, DEMBELE D., 2008 «Utilisation de la diversité variétale du sorgho pour valoriser la diversité des sols au Mali. » Cahiers Agricultures vol. 17, $\mathrm{n}^{\circ}$ 2, mars-avril 2008

BERLINET A, DEVROYE L., 1989 «Statistique et analyse des données : Estimation d'une densité : un point sur la méthode du noyau » tome 14, no 1 (1989), p. 1-32

CONCHITA M. G. KEDOWIDE, « Modélisation géomatique par évaluation multicritère pour la prospection des sites d'agriculture urbaine à Ouagadougou ", Vertigo - la revue électronique en sciences de l'environnement Volume 10 numéro 2 , mis en ligne le 30 septembre 2010, 
consulté le 03 septembre 2013. URL : http://vertigo.revues.org/10368 ; DOI : 10.4000/vertigo.10368.

CRDI, 2005. "Conservation et utilisation durable de la biodiversité agricole » guide de référence, 286 pages.

DJONDANG K, GAFSI M 2002 « Caractérisation des exploitations agricoles en zone soudanienne du Tchad Contribution pour la rechercheaction-développement » Acte du colloque, 27-31 mai 2002, Garoua, Cameroun. Page 9

DUFUMIER M., 2005 «Etude des systèmes agraires et typologie des systèmes de production agricole dans la région cotonnière du Mali » Document de projet PASE pages 83

GOMEZ L, al 2008 « Spatial aggregation: Data model and implementation » Information Systems 34 (2009) 551-576

HOUNTONDJI Y C H., 2008 «Dynamique environnementale en zones sahélienne et soudanienne de l'Afrique de l'Ouest : Analyse des modifications et évaluation de la dégradation du couvert végétal. » Thèse de Doctorat à l'université de Liège 2008.

IADES., 2013 «L'Exploitations Agricoles Familiales au Burkina Faso » Rapport provisoire juillet 2013

JOOST, S. (2008) «la dimension spatiale en écologie moléculaire Science de l' information géographique et conservation des ressources génétiques végétales et animales, 51-57.

JULIER B., 2010 « Diversité intra-spécifique et performance des cultures fourragères pérennes » Le Sélectionneur Français 2010 (61), 85 - 96

KOFFI K J et al., 2008 « Analyse de la distribution spatiale des Acanthaceae en Afrique Centrale et comparaison avec les théories phytogéographiques de Robyns, White et Ndjele » article Sciences \& Nature Vol. 5 N $^{\circ}$ : 101 - 110 (2008)

MEATEU., (2001) «Stratégie nationale en matière de diversité biologique ». Tome I et Tome II.

NGUYEN-HUU T, AUGER P., 2007 «Applications de méthodes d'agrégation de variables à l'analyse de modèles spatiaux de dynamique des populations » 2007 International Conference in Honor of Claude Lobry Page 16

PINTAUD J.C., 2008 « Modèle de domestication et structure de l'agrobiodiversité du palmier dattier Phoenix dactylifera L.» collection Colloques et séminaires Paris, 2010

PIRON M., 1993 "Changer d'échelle : une méthode pour l'analyse des systèmes d'échelles » L'Espace géographique, 1993, no 2. Page 19

RAYMOND R., 2008 « Les dynamiques paysagères. Retours d'expériences et de réflexions " Atelier transfrontalier franco-anglais du 27 au 29 Mai 2008. 
SANOGO K., (2011) «identification et validation d'indicateurs pour l'évaluation de la biodiversité agricole en zone cotonnière du mali : Etude de cas dans les villages de Kanian, Kaniko et Siramana » Mémoire de DEA page 5

SIE M., 1992 « Analyse de la diversité génétique des variétés traditionnelles de riz (oryza sativa L et glaberrima Steud.) du Burkina Faso » Mémoire de DEA à la Faculté des sciences et techniques de Montpellier.

TOURE, A.S., (1992) «Ecologie et production primaire des pâturages au Moyen-Bani-Niger, Mali » Thèse de doctorat, Université Laval, Québec. Pages 250

YOSSI H et DEMBELE F « Dynamique de la végétation post-culturale en zone soudanienne du Mali, évolution de la composition floristique et de la strate ligneuse »

http://cybergeo.revues.org/ consulté le 27 août 2013 à 10 h 30 min

http://fr.wikipedia.org/wiki/Minianka_\%28peuple\%29 consulté le 03 septembre $2013 \quad$ à $14 \mathrm{~h} 30 \mathrm{~min}$ http://www.planete-burkina.com/ethnies_burkina_faso.php consulté le 03 septembre 2013 à 14h34min

http://sig2011.esrifrance.fr/cepam_mmgd.aspx consulté le 23 octobre 2013 à 11 h30 min 